\title{
The Limits of Indicators of Wealth and Poverty through the Prism of a Systemic Approach of Zakatable Assets
}

\author{
Abderrazak Belabes \\ Professor in Islamic Economics Institute, King Abdulaziz University, Jeddah, \\ Saudi Arabia
}

\section{ABSTRACT}

The study aims to explore the limitations of financial indicators of wealth and poverty in the light of a systemic approach, which considers zakat assets as a network for processing resources and circulating energy in all parts of the whole. This allows human communities, each in its way, to find the right balance between performance and resilience in the long term in all circumstances, particularly in times of crisis and pandemic. Among the most important results reached by the study: the need to design indicators that are not only based on the quantity of money held by people, to highlight the quantities, volumes, sizes and areas related to resources to preserve the diversity of living things and ecosystems. The study recommends rehabilitation of the role of local actors in the design of indicators so that they are not the exclusive prerogative of international experts who are far removed from the daily concerns. This promotes freedom of initiative in the governance of local affairs in favor of the 'de-financialization' of human life and the introduction of currencies that respect local values.

Keywords: Assets of zakat, indicators, wealth, poverty, systemic approach

\section{INTRODUCTION}

The simple things in life, which are part of the common good of humanity, are still there. However, they sometimes tend to be forgotten, distorted, emptied of substance, and not appreciated at their true value. What matters is not so much to lead a simple life - everyone is free to conceive the life that suits them - as to develop methods of analysis that are equal to simple but essential facts, to what they encompass as meaning, values and scope, to be able to determine what really matters to preserve it, to prevent it from being lost under the influence of quantitative logic and even worse to conformism in any form whatsoever.

Knowing that the sacred texts, which express many things in a few words (jawāmi' al-kalim), contain a multitude of meanings and ranges of which a significant part remains unexplored, the present study is based on texts, dedicated to assets subject to zakât (amwāl zakawiyah), to explore the limits of wealth and poverty indicators widely used in both international studies and those aimed at analyzing the potential effects of zakāt, both at the macroeconomic, mesoeconomic, and microeconomic levels. While observations expressed most often in figures are far from everyday usage, indicators prevent us from seeing the essential things and calculations do not capture simple facts.

After highlighting the need for a renewed reading of assets subject to zakāt and the performative character of economic indicators, the study analyzes indicators of wealth and poverty under the prism of assets subject to zakāt. The conclusion presents the main results and 
emphasizes the need for local actors to reclaim indicator questions as part of a process of local initiatives that promote commitment to the life of the City.

\section{FOR A RENEWED READING OF THE ASSETS SUBJECT TO ZAKAT}

According to the sacred texts, here Qurān and Sunnah, the assets subject to

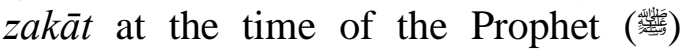
encompass four main categories: herds (camels, cows, sheep), agricultural products for human consumption and likely to be conserved, gold and silver, and goods for trade (al-Qaradhawi, 2000, 1: 53-182). This non-exhaustive list, of which some components may be associated with a bygone era, proves to be crucial to better rethink the problems associated with the link between zakāt and indicators of wealth including poverty under the reign of quantity (Guénon, 1945).

The history of humanity is linked to that of agriculture, i.e. to the domestication of plants, animals and the development of the techniques necessary to cultivate or raise them. Human survival always depends on the amount of food available. Civilization, in the first sense of the word, corresponds to the way of life of the peoples who adopted agriculture. Money then appeared, in many forms, to make exchanges more fluid when necessary. It is only one of many assets; it is not a medium that regulates social relations and infiltrates the entire sphere of life in the City, as illustrated in Figure 1. In this way, goods carry not only an original meaning, but a morality of attitudes and norms. The unbridled commodification of goods dilutes these dimensions as well as the sense of related values. For example, the camel carries values such as endurance, temperance, and sobriety which is characterized by an absence of superfluous ornaments. Most descendants of the nomads, now settled in cities, have lost the sense of these values and consider the camel as the object of a fruitful business. To show their opulence, they turned to the standardized products, primarily fourwheel drive cars, under the effect of mimetic desire (Girard, 1961).

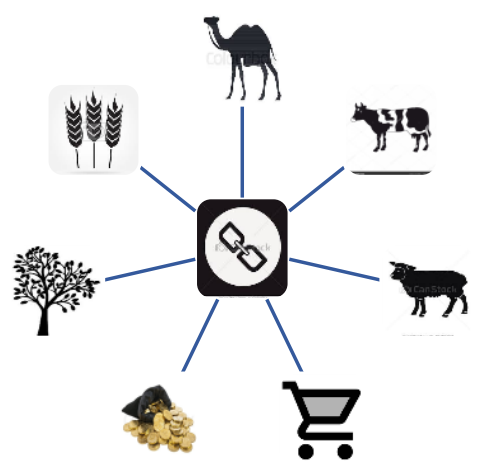

Figure 1. Assets subject to zakat

Source: Developed by the author

This renewed approach, which has its roots in the heart of human civilization, leads us to go beyond the literal reading and to appropriate classical texts in the light of the progress of scientific research, across all disciplines and beyond social sciences, to the dangers that threaten the planet and the challenges facing the human species. This emphasizes, in a fundamental way, the units of measurement which are involved in the calculation of the assets subject to zakāt, namely the quantities, the masses, the volumes, the lengths, and the duration with regard to the condition of the lunar year (hawl), as summarized in Table 1. 
Table 1. Units of measurement involved in the calculation of assets subject to zakat

\begin{tabular}{|l|c|l|}
\hline \multicolumn{1}{|c|}{ Type of Assets } & Percentage & Referent of measurement \\
\hline Herds & Variable by type & Quantity, duration \\
\hline Agricultural products & $5 \%, 10 \%$ & Mass, volum, duration \\
\hline Gold, silver, money & $2,5 \%$ & Mass, duration \\
\hline Goods for trade & $2,5 \%$ & $\begin{array}{l}\text { Mass, quantity, } \\
\text { area, length, duration }\end{array}$ \\
\hline
\end{tabular}

Source: Compiled by the author

As regards the exact physical quantities, these units of measurement are related to the real economy and the daily life of the populations beyond the monetary appreciation and the price signal that turns out to be a delusion. What guides the decisions of the players in the global financial markets is not so much the price signal as the volatility driven by unbridled speculation to take advantage of price differentials, even if only for a concise period (Bouleau, 2018).

Such an analysis overlaps with the studies that led to the need to construct indicators in quantity, mass, volume and surface (Bouleau, 2012: 101; 2017: 34), like those presented by the famous Report of the Club of Rome 'Limits to Growth' (Meadows et al., 1972: 160) and its update (Meadows et al., 2004: 241). Some of these indicators would highlight, for example, changes in social health (Jany-Catrice, Zotti, 2009) and natural heritage (greenhouse gas emissions and carbon footprint) (Paillet, Bouleau, 2016). Other initiatives focus on the ecological footprint or thresholds of irreversibility (Rockström et al., 2009). What is important is to highlight general trends in social health and pollution emissions in order to have an in-depth discussion on how to improve these trends (Méda, 2015).

Thus, humanity has an invaluable heritage of knowledge that is rooted in the expert work of normal people acquired over the centuries. However, she does not always know how to approach it with discernment in order to grasp its secret melodies, under the intoxication of civilization in love with gadgets of all kinds (Massignon, 1950), which have made people lose their sense of reality and plunged them into endless mimetic rivalry (Girard, 1961). Most economic indicators, far from being neutral techniques, support this permanent leap of desire and frustration by ignoring the societal right recognizing each human group ('umrān basharī), in the sense of Ibn Khaldun (2001: 42), the freedom to follow one's economic life trajectory embedded in the local social fabric (Polanyi, [1944] 1985: 104), free from any pre-established economic classification like 'developed/underdeveloped' (Rist, 2009), 'competitive/non-competitive' (Group of Lisbon, 1996).

\section{THE PERFORMATIVITY OF THE ECONOMIC INDICATORS}

Academic research has shown that economic indicators carry a vision, i.e. divisions of the world (Belabes, 2001). This denotes their performative character (Ottaviani, 2015, Demailly et al., 2015), in the sense of Austin ([1961] 1970), where speech, or any other form of human expression, can be direct action and not a representation or description of a thought. 
This radically changes the status of statistical tools: once indicative, they become performative, by a loop effect, since agents are encouraged to adapt their behavior to the characteristics of the indicator (Brossard, Colletis, 2011). Indicators, far from being potential catalysts for paradigmatic change, are the tools for legitimizing a status quo in the conduct of societies. Hence, the need for a scientific debate to distinguish the indicators likely to bring a change of direction in the orientation of societies, of those which in their modes of construction, include the ferments of a system which they claim to go beyond. As Alain Desrosières (2014: 275) points out, "for a statistic to play its social role as an alleged neutral referent, above parts of a conflict or social groups, it must be instituted, guaranteed by democratic procedures themselves legitimate. It helps make reality and not just reflect it."

The performative nature of economic indicators is reflected in statistics. One of the difficulties in studying statistics comes from their use as an argument to suggest certain progress and therefore justify the introduction of certain measures that seem, at first sight, to concern themselves with the fate of the most deprived, through a carefully designed vocabulary, taking into account repeated criticism). According to a recent World Bank report (2018: 1),
"in 2015, an estimated 736 million people were living below the international poverty line, or $\$ 1.90$ in purchasing power parity in 2011. In 1990, there were 1.9 billion of them. In a quarter of a century, 1.1 billion people (on a net balance) have escaped poverty

\section{and improved their standard of living ".}

In other words, it is necessary to produce before distributing through the strict application of the recommended policies that alone will allow emerging countries to benefit from economic growth that matches their ambitions and ensure sustainable development and the well-being of their populations.

A change in the threshold, however small, will have a real impact on the number of poor people in the world. The statistics are not neutral a priori. Only the reconstitution of their production and use chains makes it possible to grasp their real scope and unstated objectives. The World Bank has set itself the goal of eradicating extreme poverty around the world in 2030. But the slowdown in growth, its experts note, makes this goal more difficult to achieve. In other words, it is necessary to produce before distributing through the strict application of the recommended policies that alone will allow poor countries to benefit from economic growth that matches their ambitions and ensure sustainable development and the wellbeing of their populations (World Bank, 1994).

Beyond the human suffering associated with the implementation of the recommended policy, the societies concerned are confronted with fundamental changes in their cultural specificities in favor of a single model, where the only recognized values are competition, enrichment and individual promotion. If this trend continues, it would inevitably lead to an irreparable impoverishment of the cultural heritage of all humanity (Dujardin et al., 2003).

This problem is lacking in contemporary literature that combines zakāt and GDP, traditionally used to 
assess the wealth of nations without looking at the performative character of the indicator and its impact on cultural diversity and the way of perceiving the world; because any indicator gives an inevitably restrictive interpretation of the reality it claims to apprehend and makes it intelligible.

\section{ASSETS SUBJECT TO ZAKAT AT WEALTH INDICATORS}

The percentage of zakāt to gross domestic product is often used as an indicator by researchers (Hashem, ElSha'er, 2015: 420; Shaikh, 2016: 29; Nisthar, Nufil, 2017: 59; Ismail, 2018: 4), international organizations such as the OECD (OECD, 2017: 60), the International Monetary Fund (Alam et al., 2017: 14-15), the World Bank (Iqbal, 2013: 5), often in reference to Kahf's work (1989: 18), without taking into account the effective epistemological posture.

This amounts to measuring the contribution of zakatt to the creation of national wealth without questioning the epistemological presuppositions and limits of this indicator, which is based on a particular vision of the wealth of society: that of economists who consider that wealth comes from the production of goods and services to be sold on the market.

This conception leads to ignoring the social bond, the cultural heritage, and a whole series of essential activities, not only because they constitute a source of well-being, but more generally the fabric of daily life, i.e. to say the most important things in life by essence unquantifiable. As Bob Kennedy notes at the University of Kansas, on 18 March 1968, about the GDP: "It measures everything except that which is worthwhile" (Rogers, 2012). These activities range from what national accounts call 'non-market household production' to activities that are qualified as 'non-productive'. The wealth of a society is reduced to the production of goods and services traded on the market in the monetary sphere (Méda, 2012: 20).

Faced with this challenge, the alternative cannot be enough to develop new indicators alongside the GDP. It is necessary to take a global perspective: that of the transition towards societies of good living (Jany-Catrice, Viveret, 2018), by returning to the essential. Hence, the importance of local initiatives aimed at developing indicators that would better reflect progress or regressions of good living, in terms of human, social and ecological purposes (Jany-Catrice, 2010).

The addition of monetary added values for GDP calculation ignores what is free but valuable. This paradox leads us to rethink the very idea of wealth by seeking to extract it from its materialistic straitjacket (Rahnema, 2004). Wealth is not reduced to monetary wealth, and its multiple and qualitative rather than quantitative dimensions must be considered through its measurement (Caillé, 2012).

Furthermore, the calculation of GDP does not consider what is lost on the way in more and more cases, where growth destroys more than it creates. Multiple damages, whether human, social, or ecological, escape the growth accounts, and can rarely be evaluated in monetary terms. These damages are closely related and cannot be treated independently of each other. Thus, major public health problems are associated with pollution, the ozone hole, the greenhouse effect, and climate change.

With such limits, now shared by groups of leading researchers (Stiglitz et 
al., 2009) within international organizations (OECD, 2011), excessive reliance on GDP generates nonsense and paradoxes (Méda, Gadrey, 2013). In this sense, it is not just an inappropriate indicator - it becomes dangerous (Gadrey, 2018). For example, the destruction of tropical forests in Indonesia for the pulp, paper and palm oil industries is good for GDP. It does not matter if it is a disaster for the environment, endangered species, and aboriginal people. GDP is indifferent to the nature of the activity that ultimately generates income, just as it is indifferent to its human, social and ecological cost (Illich, [1969]1971).

The assets subject to zakāt refer to the idea that the wealth of a society is not reduced to GDP, i.e. to the sum of the monetary added values, as the currency is not the exclusive support of wealth, but only a case. The assets subject to zakāt are, first and foremost, goods of social utility that have their own value.

It should be noted, as classical legal literature states, that the Arabic word ' $m \bar{a} l$ ' refers to all that is beneficial ibn al-'Arabī, 2003, 2: 107; al-Zarkashī, 2000, 3: 31; al-Bahūtī, 1982, 3: 152). In this, people adopt this or that good for the potential benefit it provides (Ibn 'Abd al-Salām, 1990, 1: 132), given the lifestyle of society regarding available resources. This is the reason why "among the ancient Arabs, the qualifier of $m \bar{a} l$ (good) is attributed more to camels because they constituted the largest part of their amwāl (goods)" (Ibn Mandhūr, 2003, 14: 152).

The objective of economic activity is not so much to produce more to earn more as to produce what is beneficial to enable society to be sustainable, by making available to the population the goods it needs while minimizing acts likely to harm general health as described in the treaties of hisbah or are specified the rules of conduct that govern life in the city, including markets, in order to identify and minimize risks to maximize benefits.

This frame of mind belongs to the very essence of the human condition. As rightly noted by Ibn Khaldūn (2001: 346),

"the human being can only be qualified as such if he is able to attract what is beneficial to him and repel what is harmful to him and sustainably comply with this good conduct".

It extends to the entire social body. A society can only be qualified as such if it can do what is beneficial to it and push back what is harmful to it and conforming to it in a sustainable way. It is found more than four centuries later in the writings of Baron Massias (1822, 3: 201). With reference to the literature on complex systems, the sentence 'attract what is beneficial' can be synonymous with 'performance' and that 'repel what is harmful' 'with 'resilience'. If resilience and efficiency are both necessary, nature tends to favor systems which an optimal mixture of the two. Resilience requires greater diversity at the expense of efficiency, in order to increase the ability to adapt to problems that may arise. In this, GDP is a poor measure of the sustainability of systems because it measures volume, while ignoring the network structure needed to process resources and move energy to all parts of the whole. Hence the need to distinguish between bubble economy that ends up bursting sooner or later and resilient economy able to quickly overcome shocks and disturbances (Goerner et al., 2009: 77). The world today needs, more than ever, such a frame of mind which, if 
it disappears, causes society to disappear with it ${ }^{1}$.

\section{ASSETS SUBJECT TO ZAKAT AND INDICATORS OF POVERTY}

The non-exhaustive list of goods subjects to zakāt, listed above, shows that poverty is not reducible to a monetary issue. In a monetary approach to poverty, households are considered poor if their income is below a threshold that changes according to the distribution of living standards, as shown in Table 2 on the World Bank's poverty line.

Table 2. Poverty threshold established by the World Bank

\begin{tabular}{ccc}
\hline $\mathbf{1 9 9 0}$ & $\mathbf{2 0 0 8}$ & $\mathbf{2 0 1 5}$ \\
\hline 1 USD & 1,25 USD & 1,90 USD \\
\hline
\end{tabular}

Source: Compiled by author from World Bank data

In 1990, researchers proposed measuring poverty in the world against the poorest countries. They started from national poverty lines of a number of the poorest countries and converted them into a common currency using exchange rates in purchasing power parity. But as points out the Bip 40 (a barometer of inequality and poverty), an indicator developed at the local level by an association network of militant researchers and trade unionists (Concialdi, 2009), inequalities and poverty are not limited to monetary inequalities.

The monetary approach to poverty largely depends on the conventions adopted, both for the definition of income and for the setting of the threshold (Hourriez, Legris, 1998:

\footnotetext{
${ }^{1}$ It should be noted that this idea was developed before the appearance of the corona virus.
}

35). However, poverty is multifaceted; it is both a fact and a feeling, and the synthesis is difficult, to measure it, without losing the substance, nor to denature the meaning, is a dangerous exercise (Destremau, Salama, 2002).

The monetary conception of poverty leads to an arbitrary categorization which qualifies as poor people who do not necessarily consider themselves as such. The association of poverty with lack of money is recent. If it goes back to the end of the eighteenth century, under the effect of the industrial revolution, it is not neutral, because it directs thought to purely economic considerations (Polanyi, 1985: 192). Hence, the interest about poverty from the researchers in political economy (Lallement, 2012) and, more recently, from researchers in finance (Gloukoviezoff, 2008).

Most studies associating zakāt and poverty allievation (Abdullah et al., 2015; Olanipekun et al., 2015; Kasri, 2016; Arif, 2017; Mkuu, Bin Yusoff, 2017; Dutsinma, Dansabo, 2017) remain trapped of this purely monetary conception of poverty without grasping the underlying epistemological presuppositions. Hence, the tendency to consider zakāt as the following:

- A financial system (Sarea, 2012: 242).

- A microfinance tool (Ibrahim, Ghazali, 2014: 117; Hussaini, 2017: 59; Hassanain, 2015: 193; Debnath, 2015: 1; Aldosari, 2016: 33).

- A non-bank financial institution (Hassan et al., 2013: 27).

- A non-profit financial institution (Saad et al., 2014: 509). 
- A digital plateform for revenue mobilization (Yaakub et al., 2016; Mulyadi et al., 2018). Hence, the name of 'E-Zakat' or electronic zakāt.

- A bank to effectively manage the funds of the zakāt (Dakhoir et al., 2014: 62; Sudirman, 2016: 57). Hence, the name of 'zakat bank' as an extension of that of 'waqf bank' (Mohammad, 2011).

- A tool of financial inclusion (Salleh, 2015: 150; Hashem et al., 2015: 413; Yahaya, 2018: 15) that aims to mobilize more savings to promote investment and consumption, which are the drivers of growth.

- A mechanism of social finance (Alim, 2017: 233; Stirk, 2015: 3; Bayniyah, 2017; Soyan Financial Consultancy, 2017: 16; International Federation of Red Cross and Red Crescent Societies, 2018: 3-4; Muhammad et al., 2018: 141; Rasool et al., 2018: 4116).

In addition, these studies recommend investing the revenues of zakāt to better meet the needs of beneficiaries (Wan Ahmad, 2012; Alkhulaqi, 2014: 222; Gafoordeen et al., 2016).

This financialist reading amounts to closely associating zakāt with private capital for the benefit of managerial ideology that is not identified as one. Social finance, it must be remembered, consists of mobilizing private capital to generate not only economic value, but also social and environmental one (Moore et al., 2012: 116).

However, managerial ideology, beyond its mythical character as a solution to all social problems (Le Goff, 1992), has proved to be a social perversion that ultimately leads to instrumental management of the psyche and a free subjection to the cult of economic performance (Gaulejac, 2006), which is one of the characteristics of contemporary societies (Habermas, 1979; Ehrenberg, 1991).

This orientation is not surprising in the light of the statistics circulating on the Islamic financial industry in international organizations. As noted by the World Humanitarian Summit (2016: 1) in a special session dedicated to Islamic social finance: "The Islamic Finance industry's assets are presently estimated to be worth USD 2 trillion and are forecast to rise to USD 5 trillion by 2020. This is unsurprising, given that the total economy of Muslim countries is valued at USD 16.2 trillion, just behind the United States and the European Union."

Does not assimilating zakāt to a financing tool constitute a new market fundamentally for financial, fiscal, legal and shariatic engineering whose mission, proclaimed loud and clear, is to protect the quality and safety of zakāt for the benefit of the beneficiaries? Does the financialization of zakāt not offer tempting business? This may explain its recent attractiveness to private and public non-governmental organizations and United Nations agencies, especially those dedicated to humanitarian actions!

\section{CONCLUSION}

According to this study, it appears that assets subject to zakāt are not a mere list of goods, some of whose constituents seem, at first sight, to date from another time, or even from an archaic period. This list, not exhaustive, carries a vision where money is not the exclusive support of wealth, but is only a case. It refers to assets of social utility that have their own value: if money is not everything, there 
are things that cannot be bought as long as they are intended for right holders. Hence, the limits of literature that associates zakāt with monetary indicators, be it wealth or poverty. The scope of this list has not been grasped in its full meaning, because the analysis remains confined to the normative domain in the strict sense of the word, regardless of the content developed and the intentions displayed. The assets subject to zakāt carry not only an original meaning, but a moral in attitudebehaviour social relationships. The unbridled commodification of goods dilutes these dimensions and the sense of related values.

Moreover, this list basically conveys the units of measurement involved in the calculation of what is subject to the zakāt, in this case: quantities, masses, volumes, lengths, and durations. This analysis, which highlights the link with the real economy and the daily life of populations beyond monetary appreciation, overlaps with the studies that led to the need to build indicators in quantity, mass, volume, and area to highlight, by way of illustration, changes in the natural heritage (greenhouse gas emissions and carbon footprints) and social health, so that the actors can have a sort of dashboard that reports cumulative results related to the actions of agents involved in the local fabric. This gives the opportunity to improve trends in a concerted way over a long period by identifying and minimizing risks for the maximization of benefits.

In this, the study calls for a reappropriation of indicators that would do justice to the creativity and competence of local actors, so that the construction of indicators is not the exclusive domain of experts and public decision-makers. It seems difficult to imagine that a single player, however competent, can take care of this mission without any potential conflict of interest. Hence the shift from expert measurement to a local consultation in the development of indicators to protect against any risk of excess that has taken hold of our contemporary societies. This necessitates the introduction of currencies that respect local values. With such specific and complementary currencies, shocks would be better absorbed.

\section{ACKNOWLEDGEMENT}

This study is funded by the Chair of Dr. Abdulhadi H. Taher for Studies of Fiqh and Accounting of Zakāt, Faculty of Economics, Jeddah, King Abdulaziz University, Saudi Arabia.

\section{REFERENCES}

Al-Bahūtī, Manșūr (1982). Kashāf alQinā', Beirut: Dar al-Fikr.

Aldosari, Bader Nasser (2016). Islamic Microfinance System and Poverty Alleviation, International Journal of Development and Economic Sustainability, Vol.4, No.6, pp.3344.

Alim, Mohammad Nizarul (2017). Utilization and Accounting of Zakat for Productive Purposes in Indonesia: A Review, Procedia Social and Behavioral Sciences, Vol. 211, 25, November, pp. 232236.

Alkhulaqi, Zuhair (2014). Istithmār amwāl al-zakāt fī mashāri' ta'ūd 'ala mustahīqiha [Investing Zakat's income in projects more profitable for the beneficiaries], Majalat alQalam, No.3, pp. 222-242. 
Al-Qaradhawi, Yusuf (2000). Fiqh alZakah, translated by Monzer Kahf, Jeddah: Scientific Publishing Centre, King Abdulaziz University.

Al-Zarkashī, Badr al-Dīn (2000). AlManthūr fĩ al-Qawa'id, Beirut: Dar al Kotob al-Ilmiyah.

Arif, Muhammad (2017). Zakat as a Mode of Poverty Alleviation, Asian Journal of Multidisciplinary Studies, Vol. 5, Issue 11, pp. 5765.

Banque mondiale (2018). Résumé de chapitre 1: Mettre fin à la pauvreté dans le monde, http://pubdocs.worldbank.org/en/8 61781537293219008/PSPR2018Ch1-Summary-FR.pdf

Bayniyah, Ai Nur (2017). Role of Zakat as Social Finance Catalyst to Islamic Banking and Economic Growth, International Journal of Zakat, Vo. 2(2), pp. 55-70.

Bouleau, Nicoals (2017). Finance et "Business as usual", Publication de l'Institut Louis Bachelier

Bouleau, Nicolas (2012). Limits to growth and stochastics, RealWorld Economics Review, Issue No. 60, 29 June, pp. 92-106.

Caillé, Alain (2012). L'idée même de richesse, Paris: La Découverte, coll. « Cahiers libres ».

Concialdi, Pierre (2009). Les indicateurs économiques alternatifs. L'exemple du Bip 40, Savoir/Agir, $\mathrm{n}^{\circ} 8$, juin, pp. 43-56.

Dakhoir, Ahmad, Luth, Thohir, Ruba'i, Masruchin, Syafa'at, Rachmad (2014). The Bank of Alm (Zakat): Ideas, Structure, and the Implementation of the Integrated Alm Management, Journal of Law, Policy and Globalization, Vol. 25, pp. 62-72.

Damien Demailly, Lucas Chancel, Lucien Lewertoski-Blanche, Laura
Brimont (2015) Les nouveaux indicateurs de richesse dans la gouvernance européenne, Working Paper IDDRI, No. 17/15, Decembre.

Debnath, Sajit Chandra (2015). The potential of zakat scheme as an alternative of microcredit to alleviate poverty in Bangladesh, Ritsumeikan Annual Review of International Studies, Vol.14, pp. 1-12.

Desrosières, Alain (2011). Entretien réalisé par Christian Mouhanna, Sociologies pratiques, 2011/1 $\left(\mathrm{n}^{\circ}\right.$ 22), pp. 15-18.

Desrosières, Alain (2014). Prouver et gouverner. Une analyse politique des statistiques publiques, Paris, La Découverte.

Destremau and Salama (2002). Mesures et démesure de la pauvreté, Paris: Presses Universitaires de France.

Dujardin, B., Dujardin, M., Hermans, I. (2003). Ajustement structurel, ajustement culturel?, Santé Publique, 2003/4 (Vol. 15), pp. 503-513.

Dutsinma1, Ahmad Maigari and Dansabo, Muhammad Tasiu (2017). Islamic Strategies of Poverty Alleviation: A Neglected Dimension of Development in Nigeria, Saudi Journal of Humanities Social Sciences; Vol2, Iss-10A (Oct), pp. 898-908.

Ehrenberg, Alain (1991). Le culte de la performance, Paris: CalmannLévy.

Florence Jany-Catrice et Rabih Zotti (2009). La santé sociale des territoires. Un indicateur de santé sociale pour les régions françaises, Futuribles, $n^{\circ} 350$, mars 2009.

Gadrey, Jean (2013). Le PIB, Un indice parmi d'autres, Revue M3, No. 5, $1^{\text {er }}$ juin. 
Gadrey, Jean (2018). Le PIB nous mène dans l'impasse, Revue Projet, 18 janvier, https://www.revueprojet.com/articles/2018-01gadrey-le-pib-nous-mene-dans-1impasse/

Gafoordeen, N., Nayeem, Mohamed Mohideen and Aslam, Abusulaim Mohamed (2016). Zakat Investment in Shariah, International Business Management, Vol. 10, Issue 12, pp. 2398-2401.

Girard, René (1961). Mensonge romantique et vérité romanesque, Paris: Grasset.

Girardm Alain et Schéou, Bernard (2013). Quelle pauvreté réduire ? Le problème de la réduction utilitariste de la richesse, Études caribéennes [En ligne], 24-25 | Avril-Août.

Gloukoviezoff, Georges (2008). La pauvreté dans les sociétés financiarisées, Regards croisés sur l'économie, 2008/2 (n 4), pp. 117 127.

Goerner, Sally J., Lietaer, Bernard, Ulanowicz, Robert E. (2009). Quantifying economic sustainability: Implications for free-enterprise theory, policy and practice, Ecological Economics, 69, pp. 76-81.

Habermas, Jürgen (1996). Connaissance et intérêt, Paris: Gallimard.

Hashem, Eman Ahmed and El-Sha'er, Shaimaa (2015). Can Zakat help to enhance financial inclusion? Case study Egypt, International Journal of Education and Research, Vol. 3, No. 3, March, pp. 413-432.

Hassanain, Khalifa M. (2015). Integrating Zakah, Awqaf and IMF for Poverty Alleviation: Three Models of Islamic Micro Finance, Journal of Economic and Social
Thought, Vol. 2, Issue 3, pp. 193 211.

Hussaini, Mustapha (2017). Islamic Micro Finance Bank: An Alternative Tool for Poverty Alleviation in Northern Nigeria, İslam Ekonomisi ve Finansi Dergisi, 2017/1, pp. 59-70.

Ibn 'Abd al-Salām, Izz al-Dīn (1990). Qawā'id al-Ahkām fi Masālih alAnām, Beirut: Al-Rayan Publishing.

Ibn al-Arabī, Muḥammad (2003). Ahkām al-Qur'ān, Beirut: Dar al Kotob al-Ilmiyah.

Ibrahim, Patmawati and Ghazali, Ruziah (2014). Zakah as an Islamic MicroFinancing Mechanism to Productive Zakah Recipients, Asian Economic and Financial Review, 4(1), pp. 117-125.

Illich, Ivan ([1969]1971). Libérer l'avenir, Paris: Seuil.

International Federation of Red Cross and Red Crescent Societies (2018). The Transformative Power of International Zakat: How zakat support from Malaysia helped communities in Kenya recover from drought, 4 May.

Iqbal, Zamir (2013). Islamic Finance and Financial Inclusion, Global Financial Development Report Seminar Series, Washington: World Bank, June 13.

Ismail, Zenobia (2018). Using Zakat for international development, K4D Helpdesk Report, Birmingham: University of Birmingham.

Jany-Catrice, Florence (2010). La longue marche vers de nouveaux indicateurs sur les territoires, Savoir/Agir, 2010/1 ( $\left.\mathrm{n}^{\circ} 11\right)$, pp. 93-101.

Jany-Catrice, Florence et Viveret, Patrick (2018). Rêver à un autre futur, Revue Projet, 20 février. 
Kahf, Monzer (1989), Zakat: Unresolved issues in the contemporary fiqh, Journal of Islamic Economics, Vol 2 (1), pp.1-22.

Kasri, Rahmatina A. (2016). Effectiveness of Zakah Targeting in Alleviating Poverty in Indonesia, Al-Iqtishad: Jurnal Ilmu Ekonomi Syariah (Journal of Islamic Economics), Vol. 8 (2), July, pp. 169-186.

Lallement, Jérôme (2012). Les économistes et les pauvres : de Smith à Walras, L'Économie politique, 2012/3 ( $\left.\mathrm{n}^{\circ} 55\right)$, pp. 4366.

Le Baron Massias (1822). Rapport de la nature à l'homme, de l'homme à la nature, ou essai sur l'instinct l'intelligence et la vie, Paris: Imprimerie Firmin Didot.

Meadows D., Randers J., Meadows, D. (2004). Limits to Growth, The 30Year Update, London: Earthscan.

Méda, Dominique (2012). Comment le PIB a pris le pouvoir, Revue Projet, 2012/6 (n³31), pp. 14-21.

Méda, Dominique (2015). Nouveaux indicateurs de richesse ? Rien n'est joué!, Alternative économiques, 9 avril.

Mkuu, Khatib Mjaka and Bin Yusoff, Mohd Effandi (2017). Zakat Institution. An Alternative for Poverty Alleviation in Zanzibar, European Journal of Business and Management, Vol.9, No.14, pp. 57-63.

Mohammad, Tahir Sabit Haji Mohammad (2011). Towards an Islamic Social (Waqf) Bank, International Journal of Trade, Economics and Finance, Vol. 2, No. 5, October, pp. 381-386.

Moore, Michele-Lee, Westley, Frances R. \& Nicholls, Alex (2012) The Social Finance and Social Innovation Nexus, Journal of
Social Entrepreneurship, Vol. 3, No. 2, October, pp. 115-132

Muhammad, Aliyu Dahiru, Maidoki, Muhammad Lawal and Sani, Usman Buhari (2018). The Role of Islamic Social Finance in Empowering Youth and Women in Sokoto State of Nigeria, Journal of Islamic Monetary Economics and Finance, Vol. 3, Special Issue, pp 141-152.

Mulyadi, Arif Rahman Hakim, Ade Sofyan Mulazid, Supriyono, and Endah Meiria (2018). E-Zakat: Redesign the Collection and Distribution of Zakat, International Conference on Islamic Finance, Economics and Business (ICIFEB). pp. 433-452.

Naziruddin Abdullah, Alias Mat Derus, Husam-Aldin Nizar Al-Malkawi, (2015) "The effectiveness of zakat in alleviating poverty and inequalities: A measurement using a newly developed technique", Humanomics, Vol. 31 Issue: 3, pp.314-329,

Nisthar S. and Nufile, A.A.M. (2017). A comparative analysis of the relationship of nature of poverty with Zakat collection and real gross domestic product: An empirical study in the context of Indonesia, Advance Research Journal of Multi-Disciplinary Discoveries, Vol. 18.0, Issue I, pp. 58-67.

OECD (2011). Compendium of OECD well-being indicators, Paris: OECD.

OECD (2017). A Decade of Social Protection Development in Selected Asian Countries, Paris: Publications of OECD.

Olanipekun, Wahid Damilol, Brimah, Aminu Nassir and Sanusi, Haruna Baba (2015). The Role of Zakat as a Poverty Alleviation Strategy and 
a Tool for Sustainable Development: Insights from the Perspectives of The Holy Prophet (Pbuh), Arabian Journal of Business and Management Review, Vol. 5, No.3; October, pp. 8-17.

Ottaviani, Fiona (2015). Performativité des indicateurs : indicateurs alternatifs et transformation des modes de rationalisation, Thèse de doctorat en économie, Université Grenoble Alpes.

Paillet, Yoan et Bouleau, Gabrielle (2016). De la mesure des émissions des gaz à effet de serre à celle du service de régulation du climat, les traductions de l'indicateur carbone, VertigO - la revue électronique en sciences de l'environnement, Vol. 16, No. 2, https://journals.openedition.org/ve rtigo/17630

Rahnema, M. (2003). La pauvreté, communication prononcée le 18 octobre au Colloque Philia/L'Agora à Orford au Québec.

Rahnema, Majid (2004). Quand la misère chasse la pauvreté, Arles: Actes Sud.

Rasool, Mohamed Saladin Abdul; Yusof, Mohd Azmil Mohd; Amran, Sharifah Adlina Tuan Sayed (2018). Enhancing Wellbeing of Low Income Household: Perspective of Zakat Recipients, Advanced Science Letters, Vol. 24, No. 6, June, pp. 4116-4120.

Rockström, J., W. Steffen, K. Noone, Å. Persson, F. S. Chapin, III, E. Lambin, T. M. Lenton, M. Scheffer, C. Folke, $H$. Schellnhuber, B. Nykvist, C. A. De Wit, T. Hughes, S. van der Leeuw, H. Rodhe, S. Sörlin, P. K. Snyder, R. Costanza, U. Svedin, M.
Falkenmark, L. Karlberg, R. W. Corell, V. J. Fabry, J. Hansen, B. Walker, D. Liverman, K. Richardson, P. Crutzen, and J. Foley (2009). Planetary boundaries: Exploring the safe operating space for humanity, Ecology and Society, 14(2), pp. 125.

Rogers, Simon (2012). Bobby Kennedy on GDP: 'measures everything except that which is worthwhile', The Guardian, 24 May.

Saad, Ram Al Jaffri, Abdul Aziz, Norazita Marina, Sawandi, Norfaiezah (2014). Islamic accountability framework in the zakat funds management, Procedia - Social and Behavioral Sciences, 164, pp. 508-515.

Salleh, Ak Md Hasnol Alwee Pg Md (2015). Integrating financial inclusion and saving motives into institutional zakat practices: A case study on Brunei", International Journal of Islamic and Middle Eastern Finance and Management, Vol. 8, Issue 2, pp.150-170.

Sarea, Adel (2012). Zakat as a Benchmark to Evaluate Economic Growth: An Alternative Approach, International Journal of Business and Social Science, Vol. 3, No. 18, September, pp. 242-245.

Shaikh, S. A. (2016). Zakat Collectible in OIC Countries for Poverty Alleviation: A Primer on Empirical Estimation, International Journal of Zakat, 1(1), pp. 17-35.

Soyan Financial Consultancy (2017). Islamic Social Financing - A Shariah Compliant Model, 28 June.

Stirk, Chloe (2015). An Act of Faith: Humanitarian financing and Zakat, 
Bristol: Global Humanitarian Assistance, March.

Sudirman (2016). Implementing "Zakat"-Based Microfinance in Indonesia, IOSR Journal of Economics and Finance, Vol. 7, Issue 5, Ver. II (September October), pp. 57-61.

Tasneem Alam, Giorgia Albertin, Abdullah Haron, Maxym Kryshko, Tokhir Mirzoev, and Hiba Zaidi (2017). Pakistan Selected Issues, IMF Country Report No. 17/213, Washington, D.C.: International Monetary Fund.

The World Humanitarian Summit (2016). Islamic Social Finance, Special Session, Istanbul, 23-24 May.

Wan Ahmad, W. M. (2012). Zakat Investment in Malaysia: A Study of Contemporary. Policy and Practice in Relation to Shari'ah, $\mathrm{PhD}$ thesis, University of Edinburgh.

World Bank (1994). Adjustment in Africa: reforms, results, and the road ahead, New York: Oxford University Press.

Yaakub, Nor Asiah, Nathasa Mazna Ramli, Nurul Aini Muhamed, and Izlawanie Muhammad (2016). Analysis of E-Payment Applications: A Case Study of One of The Zakat Institutions in Malaysia, Journal of Techno Social, Vol. 8, No. 2, pp. 9-17.

Yahaya, Muhamad Hasif and Ahmad, Khaliq (2018). Financial Inclusion through Efficient Zakat Distribution for Poverty Alleviation in Malaysia: Using FinTech \& Mobile Banking, Proceeding of the 5th International Conference on Management and Muamalah, pp. 15-31.
Abderrazak Belabes

Professor in Islamic Economics Institute King Abdulaziz University Jeddah, Saudi Arabia asbelabes@gmail.com 